\title{
Policies and Market Development to Accelerate Technological Change in the Semiarid Zones: A Focus on Sub-Saharan Africa
}

\author{
JOHN H. SANDERS \\ Purdue University \\ West Lafayette, Indiana \\ BARRY SHAPIRO \\ ICRISAT \\ Patancheru, India
}

During the past two decades (1980-2000) donors from developed countries have been promoting structural adjustment in developing countries. This generally includes getting the public sector out of an active role in the economy, moving toward an open or free-trade regime, and eliminating subsidies (Stiglitz, 2002). Policy options, such as marketing boards and input subsidies, have been discouraged, if not eliminated, as available policy tools at the disposal of most developing countries.

At the start of the 21st century, there is a reevaluation of structural adjustment prompted by worsening poverty and nutritional problems in most developing countries, the Russian and Argentine crises, and the anti-globalization movement. Even with a new paradigm succeeding structural adjustment allowing more public sector intervention, future policy is unlikely to move back to subsidies or direct governmental intervention in market activities as principal policy instruments. Nevertheless, the public sector will need to play an important role in regulation, investments in infrastructure, the provision of public goods such as research and extension, promoting institutional innovations that improve farmer access to markets such as farmer coops and credit associations, and creating an environment in which farmers, agricultural input dealers and the product marketing sectors can make money.

In previous research, we stressed that the principal constraint to new technology introduction in the semiarid zone was neither a riskier agricultural sector combined with risk avoiding behavior of low income farmers nor labor scarcity but the availability of quality land (Sanders et al., 1996; on risk see Anderson, 2002). Technological change then needs to focus upon four components (not all

Copyright (C) 2006. American Society of Agronomy, Crop Science Society of America, Soil Science Society of America, 677 S. Segoe Rd., Madison, WI 53711, USA. Dryland Agriculture, 2nd ed., Agronomy Monograph no. 23. 
are technology) for the semiarid zone: (i) increasing water availability, (ii) improving soil fertility, (iii) developing new cultivars to take advantage of these improvements, and (iv) increasing the profitability of farmers' activities.

The first three are the technology components. The fourth is the main focus of this chapter of making specific improvements in markets. To facilitate diffusion of these new technologies without resorting to subsidies or large scale, public sector involvement will require an emphasis on the improved functioning of markets, specifically the input and product markets, in order to increase farm level profitability.

In the past two decades of structural adjustment the focus of public policy has been on public sector failures. With the success of structural adjustment of reducing the role of the state and letting prices function more, it is appropriate to be concerned once more with private market failures. This includes special programs for those areas not sufficiently profitable for private sector involvement but expected to be in the future such as the seed production for the orphan crops of the semiarid regions as well as leveling the playing field in the marketing system by increasing the ability of farmers to negotiate with input suppliers and product markets.

The next three sections will treat the three principal technology components above, water, fertilizer, and seeds. Then we get into the issues of improving the markets starting with the input markets and focusing on the critical seed sector. Besides input markets, policy makers and those developing new technologies need to be concerned with the prices received by farmers and the evolution of the demand for their products. Four sections are concerned then with marketing strategies to make sure that farmers get a larger share of the income streams with technological change as new markets evolve and new product are developed.

Once input and product markets are improved for the traditional crops, some attention needs to be placed on alternative activities for both the drylands and the small irrigated areas now in market gardens. Of continuing concern to the development community is the impact of new technology on the welfare of women and children. We review the empirical evidence on this in a section. Finally, in the conclusions we consider priorities and progress in technology introduction, policy, and markets.

\section{WATER HARVESTING}

The fundamental constraint in semiarid regions is obvious from the title of the region. These areas have inadequate and irregular rainfall. However, with increased water and higher soil fertility semiarid zones have a comparative advantage over higher rainfall regions due to less disease and more sunlight. Hence, the highest crop yields in the world are regularly attained in these regions. In the USA from the late 1950s to the early 1970s aggregate sorghum [Sorghum bicolor (L.) Moench] yields were tripled to almost $4 \mathrm{mt} \mathrm{ha}^{-1}$ (Miller and Kebede, 1987, p. 7). This was as rapid a technological improvement as with the introduction of hybrid maize. This sorghum success indicates the potential of now moving from 
higher rainfall regions and obtaining higher yields in the semiarid regions in developing countries.

The main literature stress in development with water has been on irrigation. However, expanding irrigation is often either technically or economically infeasible. There is some potential to expand irrigation in sub-Saharan Africa and we return to that in a later section of this chapter. However, the main emphasis on increasing water availability needs to be on using the available rainfall better.

In the tropics and subtropics torrential rainfalls are extremely common and runoff is very high on the heavier and crusting soils. Leaching or the passing of water rapidly through the soils and below the range of the plant roots is also a common problem on the sandy soils. So the water harvesting technique will vary with the soil type and the slope.

On the heavier soils and on slopes barriers (made of dirt, stones, and/or vegetative material) to slow and stop the rain and trenches or holes ("zai" in Burkina Faso, trenches in Ethiopia, ridges and tied ridges in Mali) to hold it are increasingly observed (Vitale and Sanders, 2005). On the sandy soils there are a series of measures to slow infiltration including organic fertilizers and higher densities with inorganic fertilizers (Shapiro and Sanders, 1997). Elsewhere we have documented the high returns to these water harvesting investments on the different types of soils (Sanders et al., 1996; Shapiro and Sanders, 1997, 2002).

Various techniques for water harvesting are widely practiced in the developed and developing world. To date the most success in sub-Saharan Africa has been with the Type I technologies (Shapiro and Sanders, 2002). These are extremely labor intensive, practiced outside the crop season when there is more labor available, and generally associated with marginal agricultural conditions where the soils have already been depleted. The zai and dirt or stone bunds on the Central Plateau of Burkina Faso, the bunds and trenches in the hills of Tigray in Ethiopia involve very large labor expenditures. But adoption is widespread. Yields are often doubled but the absolute yields on these depleted soils are still very low even with the use of the Type I technologies.

Farmers would be expected to be interested in these very labor intensive technologies only when they have limited alternatives, that is depleted soils and few options outside of agriculture. Fortunately, there are also a series of Type II technologies available for the heavier soils. Type II technologies are undertaken during the crop season so generally they need to be mechanized and are most often on the more level soils before they have been depleted. The Type II technologies include the ridging in Mali done with animal traction; tied ridging has been practiced in Zimbabwe and northern Nigeria; there are at least four types of implements for tying the ridges in various stages of development (Ethiopia, Mali, Burkina Faso) for use with animal traction; improved land preparation of various types with animal and tractor implements has been done in Botswana and South Africa. Adoption of Type II technologies has not been as widespread as with Type I. However, as animal traction spreads and the opportunity cost of labor increases, we expect more rapid introduction of these technologies.

So many water harvesting techniques are in the field in sub-Saharan Africa. Higher yields and lower labor requirements are possible with the shift to Type II techniques. Relative yield gains are not as great as soils have not been depleted 
but the absolute yield gains tend to be greater than with Type I. More systematic effort needs to be put into adaptation and extension of water harvesting and water retention (for sandy soils) for the various soil, slope, and labor availability conditions. This is a critical initial investment, which then increases the returns and reduces the risks from fertilization. The combination of the two, more water and increased soil fertility, then results in a new environment with higher payoffs to new cultivars.

\section{INORGANIC FERTILIZERS}

In the late 1980s and in the 1990s in sub-Saharan Africa, relative prices of inorganic compared to organic fertilizers increased after currency devaluations and the elimination of input subsidies. The result was increased use of manure and the diffusion of techniques for improving manure quality (corralling and composting). With more composting in Mali and Burkina Faso, manure use increased and inorganic fertilizer use decreased (Sanders et al., 1996). Manure use in the Sahel, for example, is mainly confined to the small compound areas around the household where higher value crops are grown. Unfortunately, the potential for expanding the supply of manure is very limited even with qualitative improvements discussed above (Williams et al., 1993). Sufficient manure or other organic fertilizers is not going to be available to supply the basic crop nutrients (McIntire et al., 1992).

Phosphorus (P) is usually the first limiting factor in the soils of semiarid sub-Saharan Africa since the response of crops to nitrogen $(\mathrm{N})$ in these soils is conditioned on there being adequate levels of P (Christianson and Vlek, 1991). Foreign-exchange constraints discourage the use of imported fertilizer. Some Sahelian governments have thus developed their own sources of natural rock phosphate. Unfortunately, the rock generally has very low P levels and is insoluble except in higher rainfall, acidic soil environments. Even with devaluation the rock phosphate generally is so insoluble that it is not likely to become competitive with imported inorganic fertilizers (Jomini et al., 1991). The acidification to make it more soluble depends upon the availability of industrial raw materials not available in sub-Saharan Africa.

Besides $\mathrm{P}$ soils in a wide area of the African semiarid tropics are deficient in N. The cheapest sources of these two essential nutrients (by cost per nutrient unit of $\mathrm{N}$ and $\mathrm{P}$ ) are expected to be inorganic fertilizers (Sanders, 1989). There are other complementary effects from organic fertilizers, such as increased water and nutrient retention and increased biological activity but the basic nutrient content of organic fertilizers is low. In situations where soil organic matter is too low to retain the necessary water and nutrients, an organic fertilizer will need to be combined with inorganic fertilizers. Innoculation, cereal-legume rotations, mycorrhizae have the potential to provide nutrients but generally require other basic nutrients ( $\mathrm{P}$ for the first two) and sophisticated extension and management.

Both risk and environmental concerns have been raised as arguments against the more rapid diffusion of inorganic fertilizers. The risk comes from the cash outlays necessary for fertilizer purchases and the dependence upon adequate water 
for a fertilizer response. So it is critical in semiarid environments to first increase water availability as with water harvesting and to introduce public policy to support farmers in the very adverse years (Anderson, 2002). Risk insurance polices for these years are not a big change as governments (and nongovernmental organizations, NGOs) already make outlays for food aid in these years.

On the environmental issue (the water supply effect) we need to recall that overall fertilizer use is still extremely low in sub-Saharan Africa as compared with the rest of the world and especially those regions where water pollution has become a serious issue (Larson and Frisvold, 1996; Bumb and Baanante, 1996, p. 39, for $\mathrm{N}$ use). As environmental interactions continue to be researched better $\mathrm{N}$ fertilizers will be developed. Meanwhile, sub-Saharan Africa needs to use the available knowledge to improve crop yields.

There is much discussion of alternatives to inorganic fertilizers but all countries that have substantially increased crop yields have used inorganic fertilizers as a principal element of the package. Organic farming is still an expensive sideline or complementary activity. African farmers now need to use inorganic fertilizers as this is a known activity with a high payoff (Lele et al., 1989). Governments need to put inorganic fertilizer imports near the top of their import priorities or even better move to real exchange rates and facilitate the evolution of the fertilizer markets.

Over the next decade the semiarid regions will need to rapidly increase their use of inorganic fertilizers. They can decrease costs by using more pure nutrients and less compounds and with better placement (Abdoulaye and Sanders, 2005; Larson and Frisvold, 1996; Kuyvenhoven et al., 1998). Organic fertilizers are needed to complement inorganic fertilizers on the sandy soils and other poorly buffered soils (Byerlee and Heisey, 1993). Moreover, it is important to continue research to reduce the costs and external effects of inorganic fertilizers and to identify low cost complementary fertilization activity. Nevertheless, sub-Saharan Africa needs to take advantage now of the available technology and rapidly diffuse inorganic fertilizers rather than continue waiting for the substitutes (some combination of manure, intercropping, rock phosphate, legumes, livestock-crop interaction, and low soil fertility tolerant cultivars) that have been promised for the past two decades and are still not forthcoming.

\section{PUBLIC SUPPORT FOR DEVELOPING NEW CULTIVARS}

The initial programs in semiarid sub-Saharan Africa after the major droughts of the early 1970s and 1980s were focused upon varietal improvement. There have been few successes of cultivar-alone strategies in increasing aggregate yields (for evidence for sorghum and millet [Panicum miliaceum L.], see Ahmed et al., 2000). With present low input levels relying on a cultivar-alone strategy will further deplete the already limiting, essential plant nutrients.

So the first prerequisites for higher yields in most semiarid regions are increased water availability and higher soil fertility. Some farmers have been introducing different types of water harvesting on heavier soils and others water retention within the lighter soils (Shapiro and Sanders, 2002). The debate on the 
appropriate mix of fertilization techniques continues with an evolving recognition of the primary importance of inorganic fertilizers. As more water is made available and soil fertility increased, what needs to be done about cultivar improvement?

Local cultivars have evolved to give stable responses at low input levels. They can respond to small agronomic improvements but they are expected to lodge as fertility is increased. Once there is more water and increased soil fertility, there is potential for substantial yield increases from improved cultivars built to respond to these better conditions.

Unfortunately, most breeders for semiarid regions (maize [Zea mays L.] and sorghum) have concentrated on responding to the drought threat by decreasing the time in the field of the new cultivars. Short-season cultivars have drought escape properties but do not take advantage of higher inputs by being in the field long enough to fully respond. Rather than trying to respond to drought with new cultivars, breeders need to respond to an improving agronomic environment by developing the cultivar potential for substantially higher yields.

The tripling of U.S. sorghum yields from the late 1950s to the mid-1970s (Miller and Kebede, 1987) resulted principally from improved agronomy. Approximately 33 to $39 \%$ of the increased yields were from the new hybrid seeds with the rest from the increased use of water, fertilizer, and herbicides.

In sub-Saharan Africa during the 1990s there was a decline in international support for crop improvement based on conventional breeding of new varieties including hybrids. The donor emphasis shifted to low-input methods for improving soil fertility as part of natural resource management (NRM) strategies to protect the environment. Better NRM at low input levels results in low farm income levels. So higher input levels than with the NRM programs and a renewal of crop breeding programs need to take place (Sanders et al., 1996; Ahmed et al., 2000).

With the 5- to 10-yr development and diffusion lag to get new cultivars into the field, it is critical that developing countries remount strong breeding programs now. Biotechnology can shorten this time process but these techniques are only beginning to arrive in sub-Saharan Africa. So conventional breeding activities need to be reinitiated or accelerated to anticipate these agronomic improvements that are beginning to be more rapidly diffused.

Secondly, maintenance research will continue to be important. Agriculture is a dynamic biological process so new biotic constraints will be continually emerging. Conventional breeding with biotic resistances and higher yielding cultivars has been successful in developed countries, Asia, and Latin America with rice (Oryza sativa L.), wheat (Triticum aestivum L.), maize, and sorghum. So subSaharan Africa needs to take advantage of these gains. New cultivars with biotic resistances that can respond to moderately higher inputs without lodging will enable developing countries to obtain some of the gains already achieved in developed countries and many middle income countries.

Research stations need to more aggressively produce and exchange materials, imitate the successful processes in the developed and middle income countries, and anticipate better the agronomic changes by producing the longer season, higher yielding cultivars. It is time for the breeders to reverse their response to 
the drought problem and to facilitate the diffusion of agronomic improvements to complement their cultivar gains in yield capacity and biotic resistances. The search for the super cultivar with tolerance to drought and/or low soil fertility and the other desirable yield and biotic resistance characteristics should be delegated to the alchemists or those searching for the Holy Grail. Yield at higher input levels and biotic resistances should be enough for successful breeding activity.

\section{THE INPUT MARKETS: PUBLIC AND PRIVATE ACTIVITIES}

To get these new technologies out to farmers the input markets generally need to be improved especially for seeds and to a lesser extent fertilizer and credit. In sub-Saharan Africa a paternalistic state historically has taken a large role in input supply. With structural adjustment of the last two decades the donors have pushed hard to phase down the public sector. The implicit assumption was that the private sector would automatically move into these functions. The theory seems good as the private sector is expected to be more adept than the public sector at providing quality control, responding to demand shifts, promoting technological innovation, and accelerating the diffusion process. Unfortunately, the private sector has not responded to the opportunities in many sectors or has introduced new problems (Sanders and McMillan, 2001a).

Most crops in the semiarid zone are orphan crops in which the private sector does not have an interest presently, but would be expected to have an interest with economic growth as farmers recognize the need to pay higher prices for quality seed. So we need to design public policy to facilitate this process and identify the roles of the private and public sectors over time. The experience of Sudan in the last two decades illustrates the process.

After the major drought of 1984 in the Sudan eight local companies became involved in seed production of a new sorghum hybrid. With the rapid diffusion of traditional seed and the new hybrid plus good weather the price of sorghum collapsed in 1985. Within $3 \mathrm{yr}$ all the private firms had left the industry. Fortunately, two public firms continued producing seed in the 1980s of the hybrid. The demand grew in the 1980s and private firms began re-entering the industry in the early 1990s (Sanders et al., 1996, p. 121-126). Without the public sector continuity the diffusion process would have come to a halt. As demand accelerated in the 1990s the public sector had difficulty responding. Public sectors generally have difficulty responding to rapid structural shifts and private sector trademarks are usually more effective in quality control than complaints to the government. So the interaction process was useful to both public and private sectors.

The lesson is that the orphan crop development process will require the inputs of both public and private sectors in the start up process to create a profitable environment to turn over to the private sector (Sanders and McMillan, $2001 b)$. The public-sector intermediary role in seed production needs to be focused on the initial production and regulation to ensure high quality seed production and to simultaneously convince farmers that there are economic returns to this higher-quality seed even at a higher cost. Price policy with a welfare 
objective will create an environment in which the seed sector remains public and stays dependent upon governmental largesse, with the disappearance of the seedproduction activity once the government pulls out. This is the experience of the Niger seed program of the 1970s, which collapsed when U.S. Agency for International Development (USAID) stopped subsidizing its activities.

A rule of thumb in the seed industry in the USA is the need for a 8:1 to 10:1 ratio between seed and grain prices. If the developing country has a strong research system developing the new cultivars and producing foundation seed, the development costs of the private sector could be reduced. A ratio of 4:1 to 6:1 may still be profitable. Nevertheless, this ratio is still in contrast with the public sector seed production where there is often pressure to make seed prices a poverty policy and to have differences of less than 2:1.

The public sector needs to define a transitional role from the start of the seed-production process by gradually charging higher prices for seed and by following a time table for turning the seed production and distribution business over to the private sector. One dilemma for the public sector is whether it will need to subsidize the private sector (subsidized credit, tax holidays) as is often done in developed countries to attract new firms to specific areas. The problem with subsidies is that they create a lobby and become very difficult to eliminate.

Public sector investments supporting the input and product markets are the most important role of the public sector in the development process. These include transportation and communication infrastructure, promoting innovations in farmer organizations, and research and extension support to small farmers for their public good aspects.

Regulation is also an important public function. For the small and diffuse populations and small economies of many semiarid sub-Saharan African countries, regional harmonization and even regionalization of varietal release procedures could greatly stimulate varietal development and diffusion by lowering costs for private sector firms involved in seed multiplication and delivery. Donor involvement will undoubtedly be necessary for these investments to improve the infrastructure and rationalize the regional regulations supporting agriculture.

A continuing practical implementation problem is the tendency of the private sector to neglect semiarid regions and small farmers (Lynam and Blackie, 1994; Byerlee and Hesse de Polanco, 1986). So an important state role is to not only make the public investments to reduce transactions costs for private firms by improving transportation, communication, and market information but also to facilitate the development of farmers' organizations. These organizations reduce the costs to the private sector of dealing with small farmers and enable farmers to have more negotiating power with the firms. Farmers will then be able to get discounts on input purchases, receive higher prices for greater quantities and improved quality, and more systematically search for alternative sellers of inputs and buyers of products.

Fortunately, compared with seeds, the technical problems related to establishing fertilizer markets are not as difficult to overcome (Mokwunye and Hammond, 1992). Experience from sub-Saharan Africa shows the private sector will want to become involved with inorganic fertilizer sales in semiarid regions when agriculture is profitable there and imports are facilitated by undistorted exchange 
rates. However, constraints to development of fertilizer markets do exist due to high transactions costs faced by traders selling small quantities to large numbers of small farmers and the high credit risk related to repayment failure especially in bad rainfall years. Organizing farmers into coops or credit associations can help mitigate these problems. The key here again is ensuring that organizational and institutional innovations increase access to markets and thus raise the profitability of crop production. The Senegal example of combining farmer coops or credit associations together with the introduction of inventory credit to enable farmers to bulk purchase inputs and collectively manage output sales illustrates the potential (Ouendeba et al., 2003).

\section{IMPROVED MARKETING STRATEGIES AND NEW TECHNOLOGIES}

Low farm-level food-crop prices have discouraged farmers from using more inputs and have given policy makers and researchers the impression that the primary food-crops sector could take care of itself. Unfortunately, with continuing soil degradation and nutritional problems in a high proportion of the populations of developing countries, technological change of the basic food crops cannot continue to be neglected. Higher levels of purchased inputs are required to substitute for the fertility loss of the disappearing fallow system.

There are various hypotheses for the slower diffusion process of fertilization and other intensification into semiarid zones and on traditional food crops, including higher risk levels and alternative employment opportunities. (Note that risk is reduced by the adoption of the water harvesting methods emphasized here.) Our hypothesis is that the principal factor retarding the introduction of new technologies into semiarid zones is the reduced profitability resulting from low prices received by farmers selling traditional food crops. Why?: (i) Farmers are pressed by expenditure requirements to sell at the post-harvest price lows; (ii) Major between-year price collapses of food staples result from good weather and the failure to develop alternative markets for the basic food crops; (iii) As new markets develop for processed foods and for feeds from the traditional food staples, there are increasing requirements from processors and feed mixers for improved quality and for set quantities at specific time periods. However, to receive a price premium for improved quality and quantity farmers' organizations often need to increase the market power of farmers in their negotiations with processors; (iv) The main poverty policy of many developing countries is the attempt by the public sector and NGOs to keep down the prices of the primary food commodities, especially in adverse rainfall years when food prices can increase substantially. In this and the next three sections we will discuss in turn each one of these price problems and some alternative policies to benefit farmers.

The immediate short-term opportunity is the annual food price collapse at harvest. To illustrate the extent of seasonal price variability, we questioned farmers in the Sahel about present prices and price expectations for millet in 2002 to 2003 (Table 21-1). For Sahelian farmers in the semiarid zone, the cash requirement at harvest is more pressing than the need to put aside a subsistence stock 
Table 21-1. Current and expected millet prices in four Sahelian countries, October 2002 (Source: Field interviews, Sanders and Abdoulaye, Oct. 2006).

\begin{tabular}{lccc}
\hline Country & $\begin{array}{c}\text { Millet price } \\
\text { Oct. 2002 } \\
\left(\text { FCFA kg }{ }^{-1}\right)\end{array}$ & $\begin{array}{c}\text { Expected price, millet harvest } \\
\text { 2002 (Nov.-Dec.) } \\
\left(\text { FCFA kg }{ }^{-1}\right)\end{array}$ & $\begin{array}{c}\text { Expected peak during hungry } \\
\text { period, } \dagger 2003 \text { (July-Sept.) } \\
\left(\text { FCFA kg }^{-1}\right)\end{array}$ \\
\hline Niger & 100 & 80 & 230 \\
Senegal & 250 & 100 & 300 \\
Burkina Faso & 140 & 75 & 220 \\
Mali & 168 & 90 & 225 \\
\hline
\end{tabular}

$\dagger$ The hungry period is the 2 mo before the next harvest, in this case 2003 .

of his basic commodities or the desire to maximize incomes (Vitale and Sanders, 2005). The farmer has a cash requirement to pay for labor (both hired and family), accumulated debts during the crop season, credit for inputs, school fees, marriages, naming ceremonies, and the out-migration expenses of younger family members. The farmer has to satisfy this cash requirement first; he often pays a high cost through the lower prices of his staples at harvest to respond to this need.

How much difference does the seasonal price variability make on profitability? To respond to that question we used the data for the crop year, 2001 to 2002. Rainfall quantity was normal but later than average; it was the second year of below-normal conditions so prices were higher and more variable than with the good rainfall of the late 1990s. For both average and better types of farmers, profitability per hectare practically disappears if marketing were done at the postharvest period. However, profits are substantially increased (Table 21-2) if farmers wait for the expected price recovery after 5 or 10 mo (the hungry period before the season's crop comes in).

Inventory credit, as practiced in western Niger, involves a farmer organization collecting the crop at harvest and paying the farmer the market price then. The crop is stored in the village and sold later at a higher price. The increased value of the crop is shared with farmers after paying for the costs of storage and interest costs. The farmers' organization obtains the money to pay the farmers

Table 21-2. Farm profitability and time of sale of sorghum with new technology $\left(\$ \mathrm{ha}^{-1}\right)$, Mali.

\begin{tabular}{|c|c|c|c|}
\hline armer type & & $\begin{array}{l}\text { Marketed at mid-point of } \\
\text { hungry period, } \\
2003 \text { (Mar.-Apri.) }\end{array}$ & $\begin{array}{l}\text { Marketed during hungry } \\
\text { period (July-Sept.) }\end{array}$ \\
\hline & & & \\
\hline & & & \\
\hline \multicolumn{4}{|c|}{$\begin{array}{l}\dagger \text { Farm profit (per hectare) was calculated using yields corresponding to technology introduction but } \\
\text { with modestly adverse rainfall years as in } 2000 / 2001 \text { and } 2001 / 2002 \text {. This corresponds to yields of } \\
729 \mathrm{~kg} \mathrm{ha}^{-1} \text { for average farmers and } 871 \mathrm{~kg} \mathrm{ha}^{-1} \text { for better farmers. Household labor valued at } \\
\text { prevailing wage rate of } 750 \mathrm{FCFA} \mathrm{d} \mathrm{d}^{-1} \text { (approximately } 1 \$ \mathrm{~d}^{-1} \text { using IMF } 2001 / 2002 \text { exchange } \\
\text { rate of } 744 \mathrm{FCFA}=1 \$ \text { ). This new technology uses an intermediate-season cultivar and inorganic } \\
\text { fertilizer applications of } 100 \mathrm{~kg} \mathrm{ha}^{-1} \text { for complex cereal compound (NPK:15-15-15) and } 50 \mathrm{~kg} \\
\text { ha }^{-1} \text { for urea (NPK:46-0-0). } \\
\ddagger \text { Traditional yields would be about } 500 \mathrm{~kg} \mathrm{ha}^{-1} \text { for either better or average farmer. Corresponding } \\
\text { profits to the three columns in this table would be } 17.77,63.13 \text {, and } 108.49\left(\$ \mathrm{ha}^{-1} \text { ). }\right. \\
\text { (Source: Calculated by J. Vitale from the technical coefficients of Vitale and Sanders }(2005) \text { using } \\
\text { the price variability for millet. Note that millet and sorghum prices move together.) }\end{array}$} \\
\hline
\end{tabular}


with a bank and for the first few years the loan is guaranteed by the development organization. Variations of this inventory credit system are presently being introduced into Sahelian countries by several donors with the Food and Agriculture Organization (FAO) as a principal early innovator and the International Crops Research Institute for the Semi-Arid Tropics (ICRISAT) supporting these activities and helping to extend them to neighboring countries (Ouendeba et al., 2003; ICRISAT, 2003). With inventory credit and storage, farmers can avoid selling at harvest, have cash at harvest in the form of credit, but still be able to obtain higher prices for their basic food crops by selling later in the season.

In summary, the principal short-run gains for the traditional cereals from new marketing strategies will come from the ability to avoid the sale at harvest with the increasing availability of inventory credit (Tables $21-1$ and 21-2). This enables the farmer to obtain some of the benefits of storage that the traditional marketing sector has normally received. Hence, there will be some struggle for these benefits and the farmers' organization need to help to give the farmer more market information and bargaining power as well as access to the inventory credit.

The main grain crops of the semiarid regions of sub-Saharan Africa, millet and sorghum, are not traded internationally so seasonal production cycles have a large impact on prices received by farmers. Through improved access to credit combined with collective storage and marketing, farmers can release grain gradually into the market to take advantage of seasonal price variability and keep prices elevated. Loans obtained with the grain as collateral can meet farmers' immediate needs during the interim. Farmers in Niger have been willing to adopt these approaches when the risk/reward advantage is clearly demonstrated through field trials and pilot studies (Abdoulaye and Sanders, 2005).

As more farmers participate in farmers' organization and obtain inventory credit, the aggregate effect of this introduction will be the elimination over time of most of the seasonal price variability except for the costs of interest and storage and some return for risk and for entrepreneurial activity. Hence, it is necessary to simultaneously pursue a longer term strategy with other marketing strategy components.

\section{EXPANDING MARKETS WITH PROCESSED FOODS AND FEED GRAINS}

Recently, demand-driven technology development has been emphasized by donors but this is often translated into the search for niche crops at the expense of support for the traditional food crops. These niche crops, such as green beans (Phaseolus vulgaris L.), mangos (Mangifera indica L.), and flowers, affect only a small sector of producers in the developing countries and benefit principally middle and high income consumers in the developed countries. Moreover, the production and marketing research for these niche crops can be supported by check offs or export taxes.

To improve nutrition and incomes for a large number of low-income consumers and producers it will be necessary to increase the profitability and expand the demand for the traditional food crops (Abdoulaye and Sanders, 2006). The 
shifts in consumer demands from unprocessed grains to processed food and from food grains to feed grains has occurred in the developed countries and is in process in many developing countries. Facilitating these demand shifts can moderate the price collapses of the traditional crops during good weather years. These crops are well adapted to the semiarid regions and farmers know how to grow them. The traditional food staples have been key in the development process for middle and high income countries as processed foods and feeds.

Historically, with good rainfall conditions and/or with rapid technological change, the prices of traditional food staples collapse. While falling food prices from new technology provide benefits to consumers, they slow or shut down the diffusion process because farmers' incomes collapse. Also they can leave the later-adopters in a worse situation since the price has fallen more than can be compensated for by the cost-saving effects of the new production practices. In the short run, this is a serious problem and can delay or stop the intensification process as happened with maize technology in Ethiopia after the 2001-2002 price collapse.

Why do prices collapse in good rainfall years? People can eat only so much of their basic staple, so it is difficult to increase consumption rapidly for the basic food commodities or to find new markets once the price has collapsed. Moderating these price collapses by developing new products and markets encourages a more rapid introduction of new technologies.

A recent example of price collapse has been the significant fall in cereal prices that occurred in Mali between 1998 and 2000 during 3 yr of above-normal cereal production. Cereal prices declined more than $50 \%$ (Kebe et al., 2000). ${ }^{1}$ In Ethiopia in 2001-2002 the maize price collapsed from 150 Birr/quintal to 20 to $30 \mathrm{Birr} / q u i n t a l$ in $1 \mathrm{yr}$. Ethiopian farmers could not repay their production loans and a major crisis occurred. Farmers generally consider this between season price collapse a principal factor discouraging new technology introduction.

With economic growth and the availability of new technologies, there are emerging markets for traditional cereals for both human food and feed. There are two levels of public policy intervention considered here: (i) facilitating the technology adaptation, development, and diffusion of new products based on processing-preparation techniques involving the traditional food crops; and (ii) anticipating the feed-grain revolution so that domestic producers of traditional cereals can be principal beneficiaries.

Food scientists have been applying the same techniques used for the preparation of the largely imported cereals, rice and wheat, to the more traditional domestically produced cereals, sorghum and millet. Now packaged couscous and a series of other millet products are increasingly available across the Sahel, especially in Dakar and Bamako. As with rice the new millet products can be taken

\footnotetext{
${ }^{1}$ The Mali observations are from field interviews with 19 farmers in the Segou region of Mali between 1996 and 1997 and 14 farmers in the Sikasso region of Mali in 2000. Similar issues of poor marketing channels in basic food items hinder technology advancement in other parts of sub-Saharan Africa. Government-supported programs to handle cereal surpluses through managing the supply side with price supports and storage schemes have had little success, as exemplified in Zimbabwe in the early 1980s and in Mali in the early 1970s (OMA, 1990).
} 
out of the package and boiled. Similar other products have been developed including sorghum for parboiling. Moreover, there is increasing use of sorghum and millet in other processed forms, such as baby-weaning formulas, cookies, and beer. Some of those small-scale food processors are even exporting to West Africans in Europe and the USA (Ouendeba et al., 2003).

One challenge in the semiarid areas will be ensuring that smallholders can benefit from these opportunities since processors require cereal quality control and traders want to limit transactions by dealing with either large producers or groups of farmers. Farmers' organizations will need to deal directly with processors and there will often be a struggle with the processors over who gets the seasonal price gains or the payment of a quality price differential.

Even bigger gains in demand for cereals will come with the shifting dietary patterns to a higher-quality diet with income growth. Urbanization and economic growth change the nature of food demand from basic staple food crops to a more diversified diet, which includes more animal products, fruits, and vegetables (Pingali and Rosegrant, 1995).This is a dramatic structural change in food consumption habits.

Experience in middle and high income countries has shown that the poultry industry has led the growth in fresh-meat production. Chicken (Gallus gallus) consumption rapidly increases, displacing other fresh meats (Sanders and LopezPereira, 1996). In poultry, there also are substantial innovations on the consumption side, as illustrated by the rapid growth worldwide of chicken-specialty restaurants often vertically integrated backward for the poultry supply and even feed production. The number of fast-food restaurants specializing in chicken has also begun increasing rapidly in sub-Saharan Africa as in the higher income areas of urban Kenya, Botswana, and Zimbabwe.

This growth of poultry demand substantially increases the demand for feed grains over a long period (two decades and more). Self-contained technology systems for poultry production have grown rapidly in the USA beginning in the 1950s, in Europe in the 1960s, in Brazil in the 1970s, and in Honduras in the 1980 s. $^{2}$ In the middle income countries domestic grain producers have been unable to keep pace with the feed grain demand growth so they have had to depend upon the rapid growth of feed imports.

The potential for the traditional cereal (sorghum and millet) producers to capture the demand in these emerging feed markets will depend upon their ability to compete with other grains, such as maize. As in Senegal presently, the preference of the feed-grain mixers will generally be for imported maize, which has a guaranteed quality and availability greater than the traditional local cereals. Sorghum, however, is a good animal feed and locally produced sorghum has the benefit of reduced transportation costs as compared to imported maize. The institutional changes for farmers to produce a high-value, quality controlled sorghum, that can be reliably delivered to a feed mixer, will require substantial organizational support to sorghum producers from the public sector for the for-

\footnotetext{
${ }^{2}$ For instance, in Honduras from 1980 to 1994, poultry consumption increased by $8.6 \%$ annually (Sanders and Lopez-Pereira, 1996).
} 
mation of producer groups. This shift would also be facilitated by the reduction of producer subsidies in developed countries.

\section{THE QUALITY PREMIUM}

As production is increased for food processors a number of changes are necessary. Farmers can no longer plant a mix of cultivars of different season length as a portfolio decision to reduce risk from rainfall uncertainty. Moreover, threshing can no longer be done on the ground because of the dirt and stones that become mixed with the grain. So the processors normally have to identify a preferred cultivar and farmers need to take the risk of producing just one cultivar. With a tarp ("bache") or the more expensive threshing machine farmers can keep the grain off the ground. As processing reaches higher levels, quantities and timing of availability also become more important for fulfilling contracts. This will be especially important for feed mixers in the next stage of higher incomes and consumption changes.

These qualitative changes are facilitated by the development of new food quality sorghums (white or tan) and millets. They offer cost savings to processors and feed mixers. Will the processors and feed mixers share these savings with farmers? So far in our fieldwork in the Sahel the quality premiums have been very low compared to the potential for the other two marketing innovations discussed above. Estimated payments have been from 10 to 20 FCFA (530 FCFA to the U.S. dollar in Nov. 2003, International Monetary Fund, 2003).

The main quality advantage achieved to date by some farmers' organizations in the Sahel has been the introduction of the homogeneous cultivar and the absense of dirt and stones by getting threshing done off the ground (Ouendeba et al., 2003). The alternative to threshing off the ground and paying the farmer more is for the processors to hire women to clean by hand. The labor cost is low but the quality would still be inferior as the women can separate the stones but not the dirt. Over time as labor costs increase the quality premium should also. But the farmers undoubtedly need the bargaining power of the farmers' organizations to negotiate with the processors. So the payment of the quality premium and group discounts for input costs will depend upon the size of the farmers' organization, their ability to negotiate, and their ability to deliver a quality product.

\section{THE PUBLIC SECTOR AND NONGOVERNMENT ORGANIZATIONS IN ADVERSE CLIMATIC YEARS}

The most difficult sell of the four marketing strategies is to convince governments and NGOs that higher food prices in bad rainfall years do not require public and/or NGO interventions. There are other potential poverty policies besides reducing the incentives for food producers to use inputs and to make investments in their agricultural activities. One principal beneficiary of these governmental interventions is the urban middle class, including the public sector, so 
these price reductions through imports or food price subsidies have a strong supporting lobby.

Alternative poverty policies concentrating on raising the incomes of the poor rather than reducing the incomes of farmers seem more appropriate. One obvious policy improvement would be for donors to purchase grains in adverse climatic years from the higher rainfall regions of the developing country with the drought problem rather than exporting their own cereals.

This is a long-term problem of convincing governments and NGOs that farmers need advocates in the public sector concerned with their profitability. The second proposition, not yet accepted in many developing countries, is that higher farm level prices will lead to increased inputs, investments, and productivity on the farm. These productivity improvements then can lead to long run gradual price declines benefiting both consumers and those early adopting producers, whose costs are declining faster than prices are falling.

\section{NEW CASH CROPS FOR NICHE MARKETS}

Improvement of cereal systems in semiarid regions is clearly the entry point for agricultural transformation for most smallholder farmers. However, once cereal and legume production and farmer incomes increase, public policy to diversify agriculture will reduce regional sensitivity to weather and price variability. Diversification for some farmers can lead to specialization in new activities. Risk is reduced by diversification but income is maximized by specialization. Some farmers can specialize in improved livestock activities (Sanders et al., 1996). New cash crop systems also have potential for both rainfed and irrigated conditions.

Annual cash crops with substantial potential include: roselle (Hibiscus sabdariffa L.), watermelons (Citrullus spp.) and sesame (Sesamum indicum L.) (ICRISAT, 2003, IPALAC, 2003). Promising perennials include the domesticated indigenous fruit-bearing tree Ziziphus mauritiana Lam. (now being called "Pomme de Sahel" or "apple of the Sahel"), acia (Acacia colei Maslin \& L.A.J. Thomson) for leguminous mulch, firewood, and poultry feed, physic nut (Jatropha curcas L.) for bio-insecticide and oil, and others.

Production and quality-controlled processing of roselle (a member of the Hibiscus family) by smallholders in Niger for export to Europe has doubled since 2002 and was 200 ha in 2004. (IPALAC, 2003). In the Cape region of South Africa the leaves of the wild redbush [Aspalathus linearis (Burm. f.) R. Dahlgr.] are collected by farmers for export as Rooibos tea. Organizing farmers for collection and processing has resulted in increasing the farm gate price about three times (Rogers, 2003). Other developing niche products and marketing opportunities amenable to rainfed production by smallholder farmers include the emulsifier gum arabic (Acacia senegal) that is used by soft drink and confectionary industries, physic nut-which has five times the insecticide level of neem, carob tree (Ceratonia siliqua L.), and Shepherds tree [Boscia albitrunca (Burch.) Gilg $\&$ Gilg-Ben.], shea butter for export to cosmetics manufacturers (Vitellaria), guar gum from cluster bean [Cyamopsis tetragonoloba (L.) Taub.], medicinal products 
such as the leaves of miracle tree (Moringa oleifera Lam.), olive (Olea europaea L.), néré [Parkia biglobosa (Jacq.) Benth. Ex g. Don f.], and tamarind (Tamarindus indica L.) for soft drinks (IPALAC, 2003).

Some farmers close to urban markets and with access to groundwater can expand their small plots following the African tradition of market gardens. The groundwater potential in Sub-Saharan Africa remains largely untapped. Only $0.2 \%$ of recoverable safe yield and $0.02 \%$ of the groundwater held in reserve is presently used (Sonou 1994). Profitability of market gardens can be substantially improved (three to five times) using technologies such as low-pressure drip irrigation combined with improved seeds and fertilization (IPALAC, 2003).

Potential new irrigated crops for the semiarid areas of sub-Saharan Africa include dates (Phoenix dactylifera L.), fig tree (Ficus carica L.), grapes (Vitis spp.), pomegranate (Punica granatum L.), pomelo (Citrus maxima Merr., Burm. f.) and other citrus species, mango, apples (Malus spp.), moringa, guava (Psidium spp.), passion fruit (Passiflora edulis Sims), and more. Heat-tolerant varieties of tomato (Lycopersicon esculentum Mill.), lettuce (Lactuca sativa L.), and melons and early onion (Allium spp.) varieties are also being evaluated and selected (IPALAC, 2003).

Recent successes show that irrigated niche crops can benefit smallholders even under the harsh agro-ecological conditions of the semiarid zones. The exploitation of groundwater for agricultural production has to be combined with high value crops and assured markets, again together with the organization of farmers to enable them to take advantage of market opportunities. The basic requirement is an assured source of groundwater and this exists in many semiarid zones. The key will be integrating the production practices of new activities with marketing and ensuring quality control. Factors that militate against groundwater exploitation for agricultural production can include the high cost of drilling wells and lifting water onto the land. Moreover, the domestic markets are often thin so exports or good domestic information and distribution are required.

Clearly, the number of farmers who can do these new activities will be limited by the size of the market, which will be much more limited if production is for a domestic market. However, export markets for new products can also be risky when farmers from many regions become involved.

\section{NEW TECHNOLOGIES AND THE WELFARE OF WOMEN}

A continuing issue of the development community for the low income rural areas is the impact of proposed changes, such as new technology introduction and new marketing strategies, on the welfare of women and children. How does this sector of the labor market perform? What will be their share of the gains from new technology? Can different technologies and/or policy changes be developed to increase their share of the future income streams?

There is a general consensus that: men receive most of the gains from technological change in semiarid agriculture in Sub Saharan Africa; with the introduction of new technology women are required to work more on the com- 
munal or family fields; as a result women have less time to work on their private fields. ${ }^{3}$

In the early stages of the development process it is clear that all the family is working for their survival or subsistence. For this work family members are fed, clothed, and housed. But what happens with the new income streams resulting from technological change. Do women and children benefit?

So our first concern is whether there is a within household labor market. Are the women paid wages for their activities within the household and what determines these wages? Wages included all payments to women in grain above their subsistence requirements, money, and presents after the harvest (the predominant form of payment) The determinants of these wages are then from traditional labor market theory the extent of technology introduction, the opportunity costs of the women, and their bargaining power. The new technology was the introduction of the cotton technology package (new cotton cultivars and associated inputs including inorganic fertilizers and pesticides). From 1966 to 1986 cotton yields in Burkina Faso increased by five to sixfold and similar yield gains have been obtained in other Francofone cotton producers in Sub-Saharan Africa. (Sanders et al., 1996, p. 55). All the classic determinants of wage rates were highly significant in this within family wage rate regression (Lilja et al., 1996). So women in the family are paid more by their husband when there is new technology introduced, when women have other opportunities for income outside the farm, and when they have more bargaining power. To many, this demonstration that within-family transactions functioned like any other labor market was surprising.

Is this payment for women for the additional labor required by new technology introduction sufficient to cover the cost to them of the reduced time spent on their private plot? We estimated that the reduced value of production on their private plots was greater than the increased wages so women lost income with the new technologies. Others have pointed out that the increased labor time required for a labor intensive technological change, such as cotton production, reduces the time that women have for the care and education of their children.

This reduced income does not answer the welfare question of whether they were better off with the new technologies. The missing component is the change in expenditure patterns within the family from the increased incomes and how this benefits women and children. To determine whether the overall welfare of women was reduced, a broader analysis of the changes in family-consumption patterns as a consequence of the higher family incomes resulting from technological change still needs to be done.

Many women in the region expressed their discontent with their increased labor and decreased incomes resulting from technological change (Lilja and Sanders, 1998). However, the positive side is that we observed several institutional changes that had the apparent objective of obtaining a larger share of the increased

\footnotetext{
${ }^{3}$ This distinction between communal or family plots and private plots is very common in West Africa but varies among ethnic groups. Most adult family members are obligated to work on the communal plots. Then the household head allocates small areas for individual use.
} 
income streams from technological change for other family members and for women.

First, household heads of the extended family have been the primary recipients of the increased income streams from new technologies. There was little difference between wages paid to men and women workers after age and task levels were held constant. So the discrimination was against all family members rather than just the women. One response in east and southern Africa has been substantial male out-migration and increasing shifts to farming by nuclear families so that income distribution is becoming more equal among primary rather than extended families (Lilja and Sanders, 1998). Secondly, within West Africa seasonal tasks are often performed by gender specific work groups for fixed fees. Historically their earnings have been spent on village functions. Increasingly, group members are now insisting on being paid their share (Lilja and Sanders, 1998; Sanders et al., 1996, Chapter 9). Since operations such as weeding and harvesting need to be performed rapidly at critical times, the bargaining power of these groups should be substantial enabling them to obtain larger shares of the increased income flows.

Technological change in agriculture will remain one of the main sources of increased income for the family, so an emphasis on improving the institutions responsible for the continued development and diffusion of new technologies will ultimately benefit both sexes. The effects of technology on women (and children) can be increased by accelerating the institutional changes mentioned above. Moreover, more attention needs to be put on increasing the opportunity costs and the bargaining power of women as this has also been shown to increase their within household wages from agriculture (Lilja et al., 1996).

Historically donor emphasis on programs for women has been on increasing the access of women to input markets for their private field production, especially for extension, credit, and fertilizer inputs. Donors have also attempted to improve markets for the agricultural products of women. This often resulted in men taking over these activities. Where women have private plots, they will benefit from input and product market (rice, vegetables from the market gardens) improvements.

However, even in the prime agricultural zones of the Sahel many women do not have access to land. In this case in southern Mali one-third of the women did not have a private plot (Lilja and Sanders, 1998). Women need to spend major portions of their time in household tasks such as gathering wood, water, preparing meals, and childcare. Technological improvements here would make a major difference on the time women have for off- farm work, for their private plots, for care and education of children, and even for leisure (Lawrence et al., 1999). So technology introduction into household activities, such as the new stoves requiring less wood, appears to be the appropriate place to start for programs focusing on improving the welfare of women (and children) in the rural areas.

\section{CONCLUSIONS}

Principal constraints to introducing a more rapid technological change process in the semiarid regions of developing countries appear to be increased effi- 
ciency in the input markets to facilitate a more rapid technology diffusion, improved marketing by farmers, and the expansion of the product market for the traditional food crops.

For the input markets the public sector needs to be the patron of the orphan food crops. These are the activities that are not presently sufficiently profitable for the private sector to be interested in but will become interesting to the private sector as the development process proceeds. Once there is a demand for quality seed at a premium price there will be private sector interest. This orphan crop support will be needed for most of the traditional food crops of the semiarid zone, including sorghum, millet, cowpea, pigeon pea [Cajanus cajan (L.) Huth], and peanut (Arachis hypogaea L.); teff [Eragrostis tef (Zuccagni) Trotter] in Ethiopia; and barley (Hordeum vulgare L.), chickpea (Cicer arietinum L.), and several other grain legumes in the Mediterranean zones. The difficult operational decision is when to phase down or eliminate the public sector activity. The activity needs to be profitable to the private sector but without indefinitely providing a subsidy.

Fertilizer markets are much easier to develop. But agriculture has to be profitable for farmers to purchase higher input levels and thereby replace the nutrients no longer available as the fallow system disappears. Improved marketing strategies will enable more farmers to purchase higher input levels.

The simplest marketing strategy measure is to develop inventory-credit programs so that farmers can avoid selling at the post-harvest price lows. When there are low rainfall years the price 6 to 9 mo after harvest can double or triple the price at harvest so obtaining the seasonal price premium is an important potential return presently for farmers. Public support of farmer organizations and credit associations can facilitate the development of inventory credit programs.

Public policy to facilitate the support of the financial sector would complement and make more sustainable donor activities to introduce inventory credit. Inventory credit has only a short- term effect because as more farmers or cooperatives hold on to the crops and sell later, the seasonal price variability will decline towards the level at which the price spread pays for storage, interest costs and a return for the riskiness and entrepreneurship of the storage activity.

Besides seasonal price variability the between-year price collapse of traditional food crops in good rainfall years is very important. In the medium and long run the most important activity for a farmer income increase is expected to be the development of new markets with further processing for food and feed. Public support of the improved performance and evolution of food processors of the traditional food crops needs to be an important priority.

Food scientists have developed methods to improve the ease of food preparation and quality of these products. There are new sectors of small-scale food processors now expanding rapidly in developing countries. Public policy can help to regulate quality, encourage competition, and improve infrastructure. These are very important activities because they will reduce the cost of inputs to farmers and increase the value of farmers' products. The combined effects will further encourage technology diffusion.

As the income growth process proceeds, the structural transformation of a shift to higher-quality diets is a pervasive phenomenon in developing countries. In developed and middle-income countries, traditional food crops have become 
feed crops and the semiarid regions contribute to this feed supply growth, especially with sorghum. By concentrating on more rapid technology introduction, the supply and costs of the traditional cereals can be reduced. They can become feeds and replace feed imports. Pressure on developed countries to stop subsidizing cereal exports would also benefit farmers in the developing countries.

As the principal response to the droughts of the early 1970s and again in the early 1980s donors emphasized the potential for the development of new cultivars. In the last decade concern shifted to natural resource management and the search for low input technologies. This has not been successful so we need to return to moderate and higher input levels and to develop new cultivars that take advantage of these improved environments and have biotic resistances. The ability of Sub-Saharan Africa to deal with the biotechnology potential and issues is still in doubt. But the ability to adapt or to borrow biotechnology improvements will be critical in the successes of future breeding activities.

Specialization in new crops has potential for some farmers. For some of the activities the improved exploitation of groundwater will be a first prerequisite. Fortunately, this groundwater is available to many farmers but in small areas. For both dryland and market garden (irrigated) crops, getting the marketing right is the starting point for ensuring the profitability. So the program for new activities needs to include production, collection, and processing while ensuring the markets. Caution is required since the markets for such niche products are often thin and they are thus prone to price collapse even to export markets if many regions are contributing these exports.

An important objective of much public policy in developing countries is to focus on increasing the welfare of women and children. This policy is needed to complement rapid technological change. Specific measures to introduce timesaving household technologies for women, such as improved stoves, are probably the first priority. Development of off-farm activities and greater bargaining power also would help increase the ability of women to obtain a larger share of the increased income streams from technological change.

\section{REFERENCES}

Abdoulaye, T., and J.H. Sanders. 2005. Stages and determinants of fertilizer use in semiarid African agriculture: The Niger experience. Agric. Econ. 32:167-179.

Abdoulaye, T., and J.H. Sanders. 2006. New technologies and improved markets for traditional food crops: Millet in Niger. Agric. Syst. (in press).

Ahmed, M.M., J.H. Sanders, and W.T. Nell. 2000. New sorghum and millet cultivar introduction in Sub-Saharan Africa: Impacts and research agenda. Agric. Syst. 64(1):55-65.

Anderson, J.R. 2002. Risk management in rural development. Rural Dev. Strategy Background Paper 7. Rural Dev. Facility, World Bank, Washington, DC.

Bumb, B., and C. Baanante. 1996. The role of fertilizer in sustaining food security and protecting the environment to 2020. Food, Agriculture and the Environment discussion paper 17. Int. Food Policy Res. Inst., Washington, DC.

Byerlee, D., and P. Heisey. 1993. Strategies for technical change in small-farm agriculture, with particular reference to Sub-Saharan Africa. In N.C. Russell and C.R. Dowswell (ed.) Policy options for agricultural development in Sub-Saharan Africa. Workshop Proc., Airlie House, VA. 23-25 Aug. 1992. Global 2000, Atlanta, GA.

Byerlee, D., and E. Hesse de Polanco. 1986. Farmers' stepwise adoption of technological packages: Evidence from the Mexican altiplano. Am. J. Agric. Econ. 68:519-528. 
Christianson, C.B., and P.L.G. Vlek. 1991. Alleviating soil fertility constraints to food production in West Africa: Efficiency of nitrogen fertilizers applied to food crops. Fert. Res. 29:21-33.

International Crops Research Institute for the Semi-Arid Tropics. 2003. 2003 Annual Report. ICRISAT, Patancheru, India. IPALAC (International Program for Arid Land Crops).

International Program for Arid Land Crops. 2003. Annual report 2003. Ben Gurion Univ. of the Negev, Ber Sheeva, Israel and ICRISAT, Patancheru, India.

Jomini, P., R.R. Deuson, J. Lowenberg-DeBoer, and A. Bationo. 1991. Modeling stochastic crop response to fertilization when carryover matters. Agric. Econ. 6:97-113.

Kebe, D., F. Fofany, and P. Traore. 2000. Impact de la baisse des prix des cereales seches sur les revenus des producteurs. Internal report. Inst. Economie Rurale, Bamako, Mali.

Kuyvenhoven, A., R. Ruben, and G. Kruseman. 1998. Technology, market policies and institutional reform for sustainable land use in southern Mali. Agric. Econ. 19:53-62.

Larson, B., and G.B. Frisvold. 1996. Fertilizers to support agricultural development in Sub-Saharan Africa: What is needed and why. Food Policy 21:509-525.

Lawrence, P.G., J.H. Sanders, and S. Ramaswamy. 1999. The impact of agricultural and household technologies on women: A conceptual and quantitative analysis in Burkina Faso. Agric. Econ. 20:203-214.

Lele, U., R.E. Christiansen, and K. Kadiresan. 1989. Fertilizer policy in Africa: Lessons from development programs and adjustment lending. MADIA discussion paper 5. World Bank, Washington, DC.

Lilja, N., and J.H. Sanders. 1998. Welfare impacts of technical change on women in southern Mali. Agric. Econ. 19:73-79.

Lilja, N., J.H. Sanders, C.A. Durham, H. De Groote, and I. Dembélé. 1996. Factors influencing the payments to women in Malian agriculture. Am. J. Agric. Econ. 78:1340-1345.

Lynam, J., and M.J. Blackie. 1994. Building effective agricultural research capacity. In J.R. Anderson (ed.) Agricultural technology: Policy issues for the international community. Cambridge Univ. Press, New York.

McIntire, J., D. Bourzat, and P.I. Pingali. 1992. Crop-livestock interaction in Sub-Saharan Africa. World Bank, Washington, DC.

Miller, F.R., and Y. Kebede. 1987. Genetic contributions to yield gains in sorghum, 1950 to 1980. In W.R. Fehr (ed.) Genetic contributions to yield gains of five major crop plants. Spec. Publ. 7. CSSA and ASA, Madison, WI.

Mokwunye, A.U., and L.L. Hammond. 1992. Myths and science of fertilizer use in the tropics. In R. Lal and P.A. Sanchez (ed.) Myths and science of soils in the tropics. ASA and SSSA, Madison, WI.

Observatoire du Marche Agricole. 1990. Le reflet: Bulletin mensuel du Marche agricole. OMA, Bamako, Mali.

Ouendeba, B., T. Abdoulaye, and J.H. Sanders. 2003. Production and marketing strategies. Concept paper 1. p. 1-14. In B. Ouendeba (ed.) Market improvements and new crop technologies in the Sahel. INTSORMIL, Univ. of Nebraska, Lincoln.

Pingali, P., and M. Rosegrant. 1995. Agricultural commercialization and diversification: Processes and policies. Food Policy 20(3):171-185.

Rogers, G. 2003. Time for tea-A landcare success story. Report from the Sixth Conference of the Parties to the UN Convention to Combat Desertification (UNCCD) in Havana, Cuba. Available at http://www.planets-voice.org/_interface/news.shtml?x = 942 (verified 9 Jan. 2006).

Sanders, J.H. 1989. Agricultural research and new technology introduction in Burkina Faso and Niger. Agric. Syst. 30:139-154.

Sanders, J.H., and M. Lopez-Pereira. 1996. Sorghum in Central America: Technological change on the hillsides and the plains. Mimeo for INTSORMIL. Dep. of Agric. Econ., Purdue Univ., West Lafayette, IN.

Sanders, J.H., and D.E. McMillan. 2001a. Agricultural technology for the semiarid African Horn. Vol. 1: Regional synthesis. IGAD/INTSORMIL/USAID-REDSO. INTSORMIL, Univ. of Nebraska, Lincoln.

Sanders, J.H., and D.E. McMillan. 2001b. Agricultural technology for the semiarid African Horn. Vol. 2: Country studies: Djibouti, Eritrea, Ethiopia, Kenya, Sudan, and Uganda. IGAD/INTSORMIL/USAID-REDSO. INTSORMIL, Univ. of Nebraska, Lincoln.

Sanders, J.H., S. Ramaswamy, and B.I. Shapiro. 1996. The economics of agricultural technology in semiarid Sub-Saharan Africa. Johns Hopkins Univ. Press, Baltimore, MD.

Shapiro, B.I., and J.H. Sanders. 1997. Fertilizer use in semiarid West Africa: Profitability and supporting policy. Agric. Syst. 56 (4):467-482. 
Shapiro, B.I., and J.H. Sanders. 2002. Natural resource technologies for semiarid regions of SubSaharan Africa. p. 261-274. In C.B. Barrett et al. (ed.) Natural resource management in African agriculture. CABI Publ., Cromwell Press, Trowbridge, UK.

Sonou, M. 1994. Tendances et perspectives de l'irrigation en Afrique sub-saharienne. Private irrigation in sub-Saharan Africa. Organization for Coop. and Econ. Dev., Paris.

Stiglitz, J.E. 2002. Globalization and its discontents. W.W. Norton \& Co., New York.

Vitale, J.D., and J.H. Sanders. 2005. New markets and technological change for the traditional cereals in semiarid sub-Saharan Africa: The Malian case. Agric. Econ. 32:111-129.

Williams, T.O., J.M. Powell, and S. Fernandez-Rivera. 1993. Manure utilization, drought cycles, and herd dynamics in the Sahel: Implications for cropland productivity. Paper presented at Nutrient Cycling Workshop, Addis Ababa, Ethiopia. 26-30 November. Int. Livestock Center for Africa, Addis Ababa, Ethiopia. 